\title{
Original article \\ Stages of change in physical activity-related behavior in adolescents from a Brazilian state capital
}

\author{
Andreia Pelegrini \\ State University of Santa Catarina at Florianópolis, Brazil \\ Diego Augusto Santos Silva \\ Federal University of Santa Catarina at Florianópolis, Brazil \\ Herton Xavier Corseuil \\ State University of West Paraná, Brazil \\ João Marcos Ferreira de Lima Silva \\ School of Medicine Estácio de Juazeiro do Norte, Brazil \\ Edio Luiz Petroski \\ Federal University of Santa Catarina at Florianópolis, Brazil
}

\begin{abstract}
The purpose of this study was to investigate the stages of change in physical activity-related behavior (EMCRAF) and their association with gender and age. A total of 1108 high school students of both sexes, from Florianópolis, State of Santa Catarina, took part in this study. A questionnaire was used to assess EMCRAF. A higher proportion of boys were in the maintenance stage $(48.1 \%)$ and a higher proportion of girls were in contemplation (24.7\%) and pre-contemplation (6.4\%) stages. Gender factor male and age range 17-18 were protective factors, which increased the likelihood of physically active behavior. Girls aged 17-18 were twice as likely to be in the contemplation stage than boys. It is important to expand knowledge about EMCRAF in adolescents and their associations with gender and age because a considerable number of behaviors established during this period of life can last into adulthood.
\end{abstract}

Keywords: behavior, adolescence, physical activity

Resumo-"Estágios de mudança de comportamento relacionado à atividade física em adolescentes de uma capital brasileira." O objetivo do estudo foi investigar os estágios de mudança de comportamento relacionado a atividade física (EMCRAF) e sua associação com as variáveis sexo e idade. Participaram do estudo 1.108 estudantes do ensino médio do município de Florianópolis. Os EMCRAF foram avaliados usando um questionário. Uma maior proporção de meninos foi encontrada no estágio manutenção $(48,1 \%)$ enquanto uma proporção maior de meninas estavam no estágio contemplação $(24,7 \%)$ e pré-contemplação $(6,4 \%)$. Os rapazes com 17 18 anos apresentaram fator de proteção para a presença de um comportamento ativo fisicamente. As garotas com 17-18 anos apresentaram probabilidade duas vezes maior de estar no estágio contemplação. O conhecimento sobre os EMCRAF em adolescentes e a sua associação com sexo e idade são importantes, pois um considerável número de comportamentos estabelecidos durante esse período pode persistir na idade adulta.

Palavras-chaves: comportamento, adolescência, atividade física

Resumen-"Etapas de cambio en el comportamiento relacionado con la actividad física de los adolescentes de la capital brasileña." El objetivo de este estudio fue investigar las etapas de cambio de comportamiento relacionados con la actividad física (EMCRAF) y su asociación con sexo y la edad. El estudio incluyó a 1.108 estudiantes de secundaria en Florianópolis. El EMCRAF se evaluaron mediante un cuestionario. Una proporción mayor de niños se encuentran en la etapa de mantenimiento $(48,1 \%)$, mientras que una proporción significativamente mayor de mujeres se encontraban en fase de contemplación $(24,7 \%)$ y de precontemplación $(6,4 \%)$. Los individuos con los 17-18 años demostró un factor de protección para la presencia de un comportamiento físicamente activo. Las niñas con 17-18 años mostraron el doble de probabilidades de estar en la etapa de contemplación. El conocimiento sobre el EMCRAF en adolescentes y su asociación con el sexo y 
edad son importantes debido a que un número considerable de conductas establecidas durante este período puede persistir hasta la edad adulta.

Palabras claves: comportamiento, adolescencia, actividad física

\section{Introduction}

Adolescence is characterized by a period of significant changes in the patterns of health-related behavior (Burke, Beilin, Dunbar, \& Kevan, 2004). These changes can include unhealthy dietary habits (Patrick et al., 2004), consumption of alcohol, tobacco and illicit drugs (National Institute on Drug Abuse, 2008) and insufficient physical activity (Sugiyama et al., 2007; Ceschini, Andrade, Oliveira, Araújo Junior, \& Matsudo, 2009).

Regular physical activity is an important lifestyle component and is associated with both promotion and maintenance of health. However, despite the known benefits of regular physical activity (control of cholesterol, diabetes, body composition, blood pressure) (Sallis, \& Patrick, 1994; Sallis, Prochaska, \& Taylor, 2000), physical activity levels decline with age (Sallis, 2000). Within this context, a number of studies were conducted with the purpose of developing models for assessing people's health-related behaviors. The stages of change approach is one such model used to investigate health-related behaviors. Although the original application of this model was used in the campaign against smoking, the accumulated results support its applications to other types of health-related behaviors, such as physical activity (Petroski, Silva, \& Pelegrini, 2009; Souza, \& Duarte, 2005; Velicer, Rossi, \& Prochaska, 1996).

The classification of individuals according to the stages of change in physical activity-related behavior makes it possible to: (i) distinguish between individuals willing to become physically active and those who are not; (ii) to differentiate individuals who have incorporated the habit of physical activity into their daily lives from those who have only recently started; and (iii) to distinguish between inactive individuals who intend to initiate physical activity and those who have no intention to do so. Progression from one stage of change to a subsequent stage can identify people who have a more favorable physical activity profile and who intend to adopt a healthier lifestyle (Dumith, Domingues, \& Gigante, 2008). Furthermore, application of the transtheoretical model can indicate which actions are more appropriate for people at each stage of change, thereby contributing to increasing the effectiveness of future interventions.

In Brazil there is a lack of studies that have investigated stages of change of behavior related to physical activity among adolescents (Dumith et al., 2008; Nahas et al., 2009; Oliveira et al., 2012). Against this background, and taking into account the importance for future intervention procedures of knowledge about young people's behavior, the purpose of this study was to investigate the stages of change in physical activity-related behavior and their associations with gender and age in adolescents from a Brazilian state capital.

\section{Methods}

This cross-sectional study is part of the project "Healthrelated physical activity levels, physical fitness and social behavior among schoolchildren from Florianópolis - Santa Catarina." Data collection was conducted in 2007 and the sample comprised high school students. The high school phase of the Brazilian education system spans three grades (the $10^{\text {th }}, 11^{\text {th }}$ and $12^{\text {th }}$ ). The students (or the person responsible for them, in the case of minors) signed free and informed consent forms, agreeing (or providing permission) to take part in the study. All intervention procedures were approved by the Ethics Committee of the Federal University of Santa Catarina (protocol 372/2006). Sample selection followed a two-stage design: first, stratified by geographic region and, second, clustered by school grades in order to obtain a representative sample of the high school students enrolled at public schools in Florianópolis. The city of Florianópolis is the state capital of Santa Catarina, in the Southern region of Brazil. Part of the city is located on the South American mainland and part is on the island of Santa Catarina. In stage one, the city was divided into five geographical regions as follows: city centre, continental region, east of the island, north of the island and south of the island. The largest school in each region was selected and then classes from that school were chosen by lots until a sample representative of the geographic area had been selected. In stage two, all adolescents in the chosen classes who attended school on the day of data collection were invited to take part.

The estimate for sample size was calculated using the following parameters: $37 \%$ prevalence of physical inactivity (Farias Junior et al., 2009), 95\% confidence interval $(95 \% \mathrm{CI})$, estimated error of $4 \%$ and design effect of 1.6. On the basis of these parameters, and considering a total population of 12,471 high school students enrolled at public schools, the estimated sample size was 858 participants. A further $20 \%$ was added to cover possible losses and so the target sample size was 1029 participants. In view of the sample frame design, which selected all students in each cluster (class) who were present on the day of data collection, a total of 1223 students were selected for the sample.

Students older than 18 years were excluded $(n=57)$ and those who did not answer the stage of change questionnaire $(n=58)$ were defined as losses. The final sample therefore 
consisted of 1108 students (437 boys and 671 girls) with an age range of 14 to 18 years. For purposes of analysis, age was grouped into three categories $(14-15,16$, or 17 18).

Participants were assigned a stage of change in physical activity-related behavior on the basis of the results of a questionnaire (Prochaska et al., 1994) asking each adolescent which option best described their current degree of involvement in physical activity. This questionnaire has been validated for use in a sample of young adults (Plotnikoff, Hotz, Birkett, \& Courneya, 2001; Cardinal, Tuominem, \& Rintala, 2003) who followed a sequence from pre-contemplation (the respondent does not intend to modify behavior in the near future), contemplation (the respondent does intend to change behavior, but not immediately), preparation (the respondent intends to change behavior within the next 30 days), action (recent change in behavior) through to maintenance (the behavior has changed and been maintained for more than 6 months). A descriptive statistical analysis was used to illustrate the distribution of the frequencies of each stage of change in the entire sample and broken down by gender, and age group. The chi-square test was used to detect associations between proportions. Since the dependent variable (stage of change) consisted of five categories, multinomial logistic regression was used to estimate associations between stage of change, gender and age group. For dependent variables, the "maintenance" category was chosen as reference group. The level of significance was set at $5 \%(p<0.05$ or $95 \%$ CI) in all tests.

\section{Results}

More than half of the adolescents studied (53.4\%) were in the pre-contemplation, contemplation or preparation stages $(5.1 \%, 18.8 \%$ and $29.5 \%$, respectively), which corresponds to inactive habitual behavior, while $46.6 \%$ were in the action or maintenance stages $(11.2 \%$ and 35.4 , respectively), which corresponds to more active physical behavior (data not shown).
Table 1 shows the proportion of adolescents at each stige of change, broken down by gender and age. The results show a difference between the sexes $(p<.05)$, with a higher proportion of boys in the maintenance stage $(48.1 \%)$ and more girls in the preparation $(30.3 \%)$ and maintenance $(27.1 \%)$ stages.

Stage of change was found to be associated with age. Girls aged 17 or 18 had a higher probability (OR=1.90; 95\% CI: $1.12-3.22)$ of being in the contemplation stage than girls aged 14 to 15 (Table 2). Among the boys, being 16 years old was protective factor, increasing the likelihood of physically active behavior (preparation stage; $\mathrm{OR}=0.53,95 \% \mathrm{CI}: 0.30-093)$ and being $17-18$ was protective factor, increasing the likelihood of physically active behavior (action stage; $\mathrm{OR}=0.35,95 \% \mathrm{CI}=0.14$ 0.89), when compared to younger students (Table 2).

\section{Discussion}

In general, a majority of the adolescents (53.4\%) from Florianópolis, Santa Catarina, were found to have physically inactive behavior. Souza and Duarte (2005) investigated stages of change in adolescents (14-19 year-olds) from the city of Recife, Pernambuco, Brazil, and found inactive behavior in $61.6 \%$ of the individuals studied. In contrast, a Belgian study reported inactive behavior in $41.3 \%$ of adolescents (12-18 year-olds) (Bourdeaudhuij et al., 2005).

Typical adolescent school activities may explain the high prevalence of inactive behavior among the adolescents studied. In this context, the physical education classes in Brazil are characterized as "free lesson" in which the sport is prioritized as the main subject of the classes (Hino, Reis \&, Anez, 2007; Fortes, Azevedo, Kremer, \& Hallal, 2012). In addition, students practice moderate and vigorous intensity physical activity only in one third of the class, which contributes little to the physical activity level (Hino, Reis, \& Anez, 2007; Kremer, Reichert, \& Hallal, 2012).

High rates of physical inactivity in adolescence are a matter for concern because these behaviors can persist into

Table 1. Distribution (\%) of adolescents across each stage of change in physical activity-related behavior, broken down by gender and age (Florianópolis, Santa Catarina, Brazil. 2007).

\begin{tabular}{lccccc}
\hline & $\begin{array}{c}\text { Pre- } \\
\text { contemplation }\end{array}$ & Contemplation & Preparation & Action & Maintenance \\
\hline $\begin{array}{l}\text { Gender* } \\
\quad \text { Male }\end{array}$ & $13(3.0)$ & $\mathbf{n}(\boldsymbol{\%})$ & $\mathbf{n}(\boldsymbol{\%})$ & $\mathbf{n}(\boldsymbol{\%})$ & $\mathbf{n}(\boldsymbol{\%})$ \\
$\quad$ Female & $43(6.4)$ & $166(24.7)$ & $203(30.3)$ & $77(11.5)$ & $182(27.1)$ \\
Age (years) & & & & & \\
$14-15$ & $20(5.6)$ & $54(15.1)$ & $109(30.4)$ & $43(12.0)$ & $132(36.9)$ \\
16 & $15(4.0)$ & $74(19.8)$ & $104(27.8)$ & $45(12.0)$ & $136(36.4)$ \\
$17-18$ & $21(5.6)$ & $81(21.5)$ & $114(30.3)$ & $36(9.6)$ & $124(33.0)$ \\
\hline$* \mathrm{p}<.05$ (chi-square test). & & & &
\end{tabular}


Table 2. Characterization of older individuals enrolled in the study

\begin{tabular}{|c|c|c|c|c|}
\hline & Pre-contemplation & Contemplation & Preparation & Action \\
\hline & OR $(95 \% \mathrm{CI})$ & OR $(95 \% \mathrm{CI})$ & OR (95\%CI) & OR $(95 \% C I)$ \\
\hline \multicolumn{5}{|l|}{ Variable } \\
\hline & \multicolumn{4}{|c|}{ Girls } \\
\hline \multicolumn{5}{|c|}{ Age (years) } \\
\hline $14-15$ & 1 & 1 & 1 & 1 \\
\hline 16 & $0.84(0.35-1.98)$ & $1.38(0.82-2.32)$ & $1.33(0.82-2.16)$ & $0.98(0.50-1.90)$ \\
\hline \multirow[t]{2}{*}{$17-18$} & $1.65(0.75-3.64)$ & $1.90(1.12-3.22)^{*}$ & $1.46(0.88-2.41)$ & $1.50(0.78-2.85)$ \\
\hline & \multicolumn{4}{|c|}{ Boys } \\
\hline \multicolumn{5}{|c|}{ Age (years) } \\
\hline $14-15$ & 1 & 1 & 1 & 1 \\
\hline 16 & $0.59(0.16-2.20)$ & $1.51(0.65-3.54)$ & $0.53(0.30-0.93)^{*}$ & $1.09(0.54-2.21)$ \\
\hline $17-18$ & $0.45(0.11-1.88)$ & $1.44(0.61-3.41)$ & $0.85(0.50-1.43)$ & $0.35(0.14-0.89)$ \\
\hline
\end{tabular}

adulthood. In contrast, evidence indicates that individuals who do engage in physical activity during adolescence have a higher probability of being sufficiently active in adult life (Azevedo, Araújo, Silva, \& Hallal, 2007). Therefore, encouraging young people of school age to engage in physical activity could be an important intervention to prevent the epidemiology of physical inactivity in adult life.

The girls studied here were mainly in the preparation and maintenance stages, whereas boys were mainly in the maintenance stage, demonstrating that girls had greater interest in changing their behavior. These results are in line with figures reported for adolescents (14-17 year-olds) (Braggion, Matsudo, \& Matsudo, 2000; Oliveira et al., 2012).

This study found that, for adolescent boys, being in the 16 and 17 to 18 years age range is a protective favor for the presence of active behavior (preparation and action stages), when compared to boys aged 14 to 15 . Older adolescent girls were, approximately, twice as likely to be in the contemplation stage than younger girls. This finding demonstrates that, although not participating regularly in physical activity, these girls wish to become physically active. One of the possible explanations for this finding may be the major concern with body perception that girls in this age group have compared the younger (Bucchianeri, Arikian, Hannan, Eisenberg, \& Neumark-Sztainer, 2013). This higher concern with body perception may reflect the desire for physical exercise (Carraça et al., 2012).

Gonçalves et al. (2007) conducted an ethnographic study of adolescents from the city of Pelotas, RS, Brazil, and found that boys receive greater social and familial support to engage in physical activities in adolescence and that many parents blame poor academic performance on time spent on outdoor activities. Moreover, recent publications show that $80.3 \%$ of $13-15$-year-old adolescents do not do $60 \mathrm{~min}$ of moderate to vigorous physical activity per day
(WHO, 2011).

Several behavioural and environmental factors a?ect levels of physical activity (Pratt et al., 2012), among then rapid urbanisation, mechanisation, and increased use of motorised transport could have caused global changes in physical activity (Assah et al., 2011). Furthermore, physical activity levels have been observed to reduce during the transition from childhood to adolescence, followed by a slight stabilization by the end of adolescence (Telama, \& Yang, 2000; Koezuka et al., 2006).

The main limitation of the present study is its crosssectional design, which prevents the drawing of conclusions relating to temporal trends in behavior changes as adolescents move between stages, which in turn would have demonstrated the adolescents' true intentions in terms of engaging in physical activities. Another limitation is the failure to investigate other factors that could be associated with the stages at the ends of the scale (pre-contemplation and maintenance), such as perceived barriers to physical activity (violence, a lack of spaces in which to practice physical activities, the built environment and the perceived environment). Despite these limitations, the data collected were from a representative sample of the high school students at public schools in the city of Florianópolis, Santa Catarina.

\section{Conclusion}

In view of the above considerations, and on the basis of the results reported here, it can be concluded that (i) the greater part of these adolescents were in the preparation or maintenance stages and most girls were inactive, while the boys were more active; (b) for boys, being aged 17 to 18 years was a protective factor, making active behavior more likely (action stage), whereas for girls, being older (17 to 18 ) was associated with a greater likelihood of being in the contemplation stage. In summary, it is important to 
accumulate knowledge about stages of change for physical activity-related behavior in adolescents and their associations with gender, age and school grade because a considerable number of behaviors established during this period of life can persist into adulthood, resulting in positive or negative health outcomes. More effective programs and interventions should be implemented at public schools in Florianópolis. They should be designed to constantly encourage and stimulate adoption of active lifestyles and must offer good quality infrastructure, accessibility, availability and provide the information and safety necessary for youngsters to develop healthy habits that will last into adulthood.

\section{References}

Assah, F.K., Ekelund, U., Brage, S., Mbanya, J.C., \& Wareham, N.J (2011) Urbanization, physical activity, and metabolic health in sub-Saharan Africa. Diabetes Care, 34(2), 491-496. doi: $10.2337 / \mathrm{dc} 10-0990$

Azevedo, M. R., Araujo, C. L., Silva, M. C., \& Hallal, P. C. (2007). Tracking of physical activity from adolescence to adulthood: a population-based study. Revista de Saúde Pública, 41(1), 6975. doi: 10.1590/S0034-89102007000100010.

Bourdeaudhuij, I., Philippaerts, R., Crombez, G., Matton, L., Wijndaele, K., Balduck, A., et al. (2005). Stages of change for physical activity in a community sample of adolescents. Health Education Research, 20(3), 357-366. doi: 10.1093/her/cyg131.

Braggion, G. F., Matsudo, S. M. M., \& Matsudo, V. K. R. (2000). Food intake, physical activity and body appearance perception in adolescents. Revista Brasileira de Ciência e Movimento, 8(1), 15-21. Retrieved from http://portalrevistas.ucb.br/ index.php/RBCM/article/viewArticle/350.

Bucchianeri, M.M., Arikian, A.J., Hannan, P.J., Eisenberg, M.E., \& Neumark-Sztainer, D. (2013). Body dissatisfaction from adolescence to young adulthood: findings from a 10-year longitudinal study. Body Image, 10(1), 1-7. doi: 10.1016/ j.bodyim.2012.09.001.

Burke, V., Beilin, L. J., Dunbar, D., \& Kevan, M. (2004). Changes in health-related behaviours and cardiovascular risk factors in young adults: associations with living with a partner. Preventive Medicine, 39(4), 722-730. doi: 10.1016/j.ypmed.2004.02.038

Cardinal, B. J., Tuominen, K. J., \& Rintala, P. (2003). Psychometric assessment of Finnish versions of exercise-related measures of transtheoretical model constructs. International Journal of Behavioral Medicine, 10(1), 31-43. doi: 10.1207/ S15327558IJBM1001_03.

Carraça, E.V., Markland, D., Silva, M.N., Coutinho, S.R., Vieira, P.N., Minderico, C.S., et al. (2012). Physical activity predicts changes in body image during obesity treatment in women. Medicine and Science in Sports and Exercise, 44(8), 16041612. doi: 10.1249/MSS.0b013e31824d922a.

Ceschini, F. L., Andrade, D. R., Oliveira, L. C., Araújo Junior, J. F., \& Matsudo, V. K. R. (2009). Prevalence of physical inactivity and associated factors among high school students from state's public schools. Jornal de Pediatria, 85(4), 301-306. doi: S002175572009000400006

Dumith, S. C., Domingues, M. R., \& Gigante, D. P. (2008). Stages of change toward physical activity: a review of literature. Revista Brasileira de Cineantropometria e Desempenho Humano, 10(3), 301-307. Retrieved from http:// www.periodicos.ufsc.br/index.php/rbcdh/article/view/4218/
16557

Farias Júnior, J. C., Nahas, M.V., De Barros, M. V. G., Loch, M. R., Oliveira, E. S. A., De Bem, M. F. L., et al. (2009). Health risk behaviors among adolescents in the south of Brazil: prevalence and associated factors. Revista Panamericana de Salud Publica, 25(4), 344-352. doi: S1020-49892009000400009.

Fortes, M.O., Azevedo, M.R., Kremer, M.M., \& Hallal, P.C. (2012). A Educação Física escolar na cidade de Pelotas, RS: contexto das aulas e conteúdo. Revista de Educação Física da UEM, 23(1), 69-78. doi: 10.4025/reveducfis.v23i1.12617.

Goncalves, H., Hallal, P. C., Amorim, T. C., Araújo, C. L. P., \& Menezes, A. M. B. (2007). Fatores socioculturais e nível de atividade física no início da adolescência. Revista Panamericana de Salud Publica, 22(4), 246-253. doi: S102049892007000900004.

Hino, A.A.F., Reis, R.S., \& Rodriguez-Añez, C.R. (2007). Observação dos níveis de atividade física, contexto das aulas e comportamento do professor em aulas de educação física do ensino médio da rede pública. Revista Brasileira de Atividade Física e Saúde, 12(3), 21-30. Retrieved from http:// www.sbafs.org.br/_artigos/54.pdf

Koezuka, N., Koo, M., Allison, K. R., Adlaf, E. M., Dwyer, J. J. M., Faulkner, G., et al. (2006). The relationship between sedentary activities and physical inactivity among adolescents: results from the Canadian community health survey. Journal of Adolescent Health, 39(4), 515-522. doi: 10.1016/j.jadohealth.2006.02.005.

Kremer, M.M., Reichert, F.F., \& Hallal, P.C. (2012). Intensidade e duração dos esforços físicos em aulas de Educação Física. Revista de Saúde Pública 46(2), 320-326. doi: http://dx.doi.org/ 10.1590/S0034-89102012005000014.

Nahas, M. V. de Barros, M. V., de Assis, M. A., Hallal, P. C., Florindo, A. A., \& Konrad, L. (2009). Methods and participant characteristics of a randomized intervention to promote physical activity and healthy eating among Brazilian high school students: the Saude na Boa Project. Journal of Physical Activity \& Health, 6(2), 153-62. Retrieved from http://journals. humankinetics.com/jpah-back-issuesJPAHVolume6Issue2 MarchMethodsandParticipantCharacteristicsofaRandomized InterventiontoPromote PhysicalActivityandHealthyEating Am ongBrazilianHigh SchoolStudentsTheSaudenaBoaProject.

National Institute on Drug Abuse (2008). National Institutes of Health. High school and youth trends. Available: <http://www. nida.nih.gov/pdf/infofacts/HSYouthTrends08.pdf>. Accessed April 23, 2009.

Oliveira, N. K. R. de Barros, M. V. G., Reis, R. S., Tassitano, R. M., Tenório, M. C. M., Bezerra, J., et al. (2012). Estágios de mudança de comportamento para a atividade física em adolescentes. Motriz: Revista de Educação Física, 18(1), 4254. doi: 10.1590/S1517-86922005000200002

Patrick, K., Norman, G. J., Calfas, K. J., Sallis, J. F., Zabinski, M. F., Rupp, J., et al. (2004). Diet, physical activity, and sedentary behaviors as risk factors for overweight in adolescence. Archives of Pediatric and Adolescents Medicine, 158(4), 385390. Retrieved from http://www.outdoorfoundation.org/pdf/ RiskFactorsforOverweight.pdf

Petroski, E. L., Silva, D. A. S., Reis, R. S., \& Pelegrini, A. (2009). Stages of behavioral change and positive perception of the environment towards physical activity among urban park users. Motricidade, 5(2), 17-31. Retrieved from http:// www.scielo.oces.mctes.pt/s cielo.ph p s cript =sci_arttext\&pid=S1646-107X2009000200003\&lng=en\&nrm $=$ iso\&ignore $=$.html.

Plotnikoff, R. C., Hotz, S. B., Birkett, N. J., \& Courneya, K. S. (2001). Exercise and the transtheoretical model: a longitudinal 
test of a population sample. Preventive Medicine, 33(5), 441452. doi: 10.1006/pmed.2001.0914.

Pratt, M., Sarmiento, O.L., Montes, F., Ogilvie, D., Marcus, B.H., Perez, L.G. et al. (2012). The implications of megatrends in information and communication technology and transportation for changes in global physical activity. Lancet 380(9838), 282293. doi: 10.1016/S0140-6736(12)60736

Prochaska, J. O., Velicer, W. F., Rossi, J. S., Goldstein, M. G., Marcus, B. H., Rakowski, W., et al. (1994). Stages of change and decisional balance for twelve problem behaviors. Health Psychology, 13(1), 39-46. Retrieved from http://www.uri.edu/ research/c prc/Publications/PDFs/By Title/ Stages $\% 20$ of $\% 20 \mathrm{Ch}$ ange $\% 20$ and $\% 20$ decisional $\% 20$ balance\%20for.pdf

Sallis, J. F., \& Patrick, K. (1994). Physical activity guidelines for adolescents: consensus statement. Pediatric Exercise Science, 6(4), 302-314. Retrieved from http://journals.humankinetics.com/ pes-back-issues/pesvolume6issue4november/physicalactivity guidelinesforadolescentsconsensusstatement.

Sallis, J. F., Prochaska, J. J. \& Taylor, W. C. (2000). A review of correlates of physical activity of children and adolescents. Medicine in Science and Sports Exercise, 32, 963-975. Retrieved from http://www.ncbi.nlm.nih.gov/pubmed/10795788

Sallis, J. F. (2000). Age-related decline in physical activity: a synthesis of human and animal studies. Medicine in Science and Sports Exercise, 32(5), 1598-1600. Retrieved from http:// www.ncbi.nlm.nih.gov/pubmed/10994911.

Souza, G. S., \& Duarte, M. F. S. (2005). Behavior change stages related to physical activity in adolescents. Revista Brasileira de Medicina Esportiva, 11(2), 104-108. doi: 10.1590/S151786922005000200002.

Sugiyama, T., Xie, D., Graham-Maar, R. C., Inoue, K., Kobayashi, Y., \& Stettler, N. (2007). Dietary and lifestyle factors associated with blood pressure among U.S. adolescents. Journal of Adolescent Health, 40(2), 166-172. doi: 10.1016/ j.jadohealth.2006.09.006.

Telama, R., \& Yang, X. (2000). Decline of physical activity from youth to young adulthood in Finland. Medicine in Science and Sports Exercise, 32(9), 1617-1622. Retrieved from http:// journals.lww.com/acsm-msse/pages/articleviewer.aspx? year $=2000 \&$ issue $=09000 \&$ article $=00015 \&$ type $=$ abstract

Velicer, W. F., Rossi, J. S., \& Prochaska, J. O. (1996). A criterion measurement model for health behavior change. Addictive Behaviors, 21(5), 555-584. doi: 10.1016/0306-4603(95)000836.

WHO. Global school-based student health survey (2011). Available: http://www.who.int/chp/gshs/en/. Accessed January 15, 2013).

\section{Authors' note}

Andreia Pelegrini is with the State University of Santa Catarina, Center for Health Sciences and Sports, Physical Education Department. Florianópolis, Santa Catarina, Brazil.

Herton Xavier Corseuil is with the State University of West Paraná, Marechal Cândido Rondon, Paraná, Brazil.

Diego Augusto Santos Silva is with the Graduate Program in Physical Education, Federal University of Santa Catarina, Research Center of Physical Education in Kinanthropometry and Human Performance. Florianópolis, Santa Catarina, Brazil.
João Marcos Ferreira de Lima Silva is with the School of Medicine of Juazeiro do Norte, Ceará, Brazil.

Edio Luiz Petroski is with the Graduate Program in Physical Education, Federal University of Santa Catarina, Research Center of Physical Education in Kinanthropometry and Human Performance. Florianópolis, Santa Catarina, Brazil.

\section{Correspondence to:}

Andreia Pelegrini

State University of Santa Catarina. Center for Health Sciences and Sports. Physical Education Department

Paschoal Simone Avenue, 358

CEP 88080-350 - Florianópolis, Santa Catarina, Brazil

E-mail: andreia.pelegrini@udesc.br

Manuscript received on February 4, 2013

Manuscript accepted on August 18, 2013

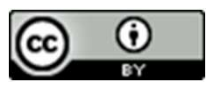

Motriz. Journal of Physical Education. UNESP, Rio Claro, SP, Brazil, eISSN: 1980-6574, is licenced under a Creative Commons License, Version 3.0. 